\title{
The Improvement of School Principal Performance of SMP Sampang through Managerial Supervision
}

\author{
Solikin* \\ Dinas Pendidikan Kabupaten Sampang
}

*Coressponding author Solikin

$\triangle$ likin_pgws@yahoo.com

\begin{abstract}
Purposed of the research is to improve Principal performance using managerial supervision. The research was conducted in three schools in Sampang. This research using school action research with two cycle, result of the research it found in cycle I that $81 \%$ of teachers understand about class supervision, but they could not implement it based on the characteristics. In cycle, there is an increase of understanding from (cycle I) on average reaches score $29,90 \%$ to $45,47 \%$. Cycle III there is an increase in supervision competence, from the average (cycle II) reaches score of $45.47 \%$ to $50.42 \%$.
\end{abstract}

Keywords

Managerial; supervision; school principal.

\section{INTRODUCTION}

According to the Directorate of Education Personnel at the Directorate General of PMPTK, in June 2008 it was suggested that performance of teachers, school principals, and staff (school administrative staff) is one of the competencies should be mastered by schools/madrasah supervisors. Competence is included in the dimensions of the competence of education evaluation. The performance of the school principal could be measured from three aspects: (a) behavior in performing the task of the school principal's behavior when carrying out managerial functions; (b) how to carry out the task in achieving the work which is reflected in his commitment as a reflection of the personality and the social competence of own, and (c) from the result of work reflect the change in the performance of the school that they leads.

Ilyas (1999) also believes that operational personnel is the best resource of an organization so that their performance evaluation becomes one of the variables that are important for organizational effectiveness. In education sector, it is important to have an effective performance appraisal tool for the professional workforce that is the most important part of management efforts to improve effective organizational performance.

Therefore, a supervisor who performs a performance appraisal should at least have four components of competence or ability: (1) understand the substance (variables) of performance to be assessed, (2) have a standard and/or formulating an assessment instrument, (3) conduct data collection and analysis, and (4) made a final judgment (Director of Education Personnel DG PMPTK, June 2008 on Teacher Performance Assessment).

The first main task refers to managerial supervision and the second main task refers to academic supervision. Managerial supervision basically provides training, assessment and assistance/guidance starting from the program plan, process, until result. Training and assistance are provided to the school principals and all school staff in school management or school administration to improve school performance. Academic supervision relates to fostering and assisting teachers in improving the quality of learning process/training and quality of student learning outcomes. Of course, all that must be based on the performance of each field.

According to Ilyas (1999: 112), performance is the appearance of the work of personnel both quantity and quality within an organization and is the appearance of individual and group work personnel. The description of performance involves three important components: (1) Objective: Determining the objectives of each organizational unit is a strategy used to improve work; (2) Size: It takes a measure of whether a personnel has achieved the expected outcomes, therefore quantitative and qualitative performance standards 
for each task and position of personnel play an important role; (3) Assessment: Performance appraisal on a regular basis is associated with the process of achieving the performance goals of each personnel. The understanding performance with a description of objectives, operational measures, and regular assessment has an important role in maintaining and improving personnel motivation.

Based on that definition, the performance of the school principal/madrasah is the result of the work achieved by the school principal/madrasah in carrying out the main tasks, functions, and responsibilities in managing the school he leads. The work is a reflection of his competence. This understanding shows that the performance of the school principal is shown by the work in concrete form, can be observed, and can be measured both in quality and quantity. The performance of the school principal in this paper is measured from three aspects: (a) behavior in performing the task of the school principal's behavior when carrying out managerial functions, (b) how to carry out the task in achieving result of the work that reflect his commitment as a reflection of personality competence and the social competence, and (c) the results of the work that reflect the changes in the performance of the school he leads.

Performance appraisal is a formal system used to assess the performance of supervisors periodically as determined by the organization. The results can be used for decision making in the context of employee development, rewarding, employee planning, compensation, and motivation. Every employee in any organization environment certainly has its main duties, functions, and responsibilities in accordance with the description of the task given by the leadership of the organization.

Based on that mentioned above, the School Action Research (PTS) is conducted as an effort to measure and improve the performance of the school principal of SMP Kabupaten Sampang through managerial supervision of Lesson Year 2015/2016. This is because so far the performance of school principals is considered insufficient, especially in running two functions of supervision and managerial. By the aim to improve the school principal's competence in school managerial and to improve the ability of the school principal in academic supervision in his school, so it will certainly greatly assist the school, especially teachers who desperately need supervision and direction from a school principal.

\section{METHODS}

The research was conducted in three schools i.e SMP Negeri 4 Sampang, SMP Negeri Atap 1 Torjun, SMP Sabilillah Sampang. The researcher chose the school based on the consideration that the school was guidance by researchers. The data in this research was collected form the events and information about the performance of school principals in running the competence of academic supervision in the school through managerial supervision. Sutopo (1996: 49-51) mentioned that data can be extracted from informants (resource persons), events or activities, documents, and archives.

The data, mostly in the form of words and the results of the school principal's supervision, are extracted from the following three sources: (1) Informants or resource persons, i.e school principals (2) Events, which are academic supervision results during the learning process. (3) Document and archives, namely written information in the form of Clinical Supervision Instrument, Learning Syllabus, Learning Implementation Plan made by the teacher.

\section{Data Collection}

Non test technique. (1) Interview (2) Observation. Test techniques: Performance and data collection tools: Non-test techniques (1) Sheet/interview guide (2) Observation sheet. Test techniques (1) Developing academic supervision instruments (2) Establishing assessment procedures (3) Recruiting academic supervision results.

\section{Data Validation}

Before any information is used as research data, the information needs to be tested for its validity so that the data obtained can be justified and can be used as a solid basis to draw conclusions. The technique that used to test the validity of the data in this study is triangulation.

Triangulation is a "data validity check technique that utilizes something else outside the data for checking purposes or as a comparison against that data. The most widely used triangulation technique is checking through other sources "(Moleong, 2005: 330). Application of triangulation to find out the difficulties experienced by the principal while supervising the teacher in the classroom learning in accordance with the characteristics of supervision in force. In this way, unilateral interpretation of the 
researcher on information can be avoided. This is done through a discussion between the researcher and school principal of SMP Sampang after the activity or document review.

\section{Data Analysis}

Data analysis technique used in this research is critical analysis and comparative analysis. Critical techniques referred to this research include the activities reveal the weaknesses and strengths of school principal participants in choosing techniques of clinical supervision in accordance with characteristics based on criteria. The result of the critical analysis is used as the basis for preparing the action plan for the next stage according to the existing cycle.

After knowing the initial condition of the school principal training result in supervising the class, the researcher plan a cycle of action to address the problems. In each cycle ends, the results are analyzed what are the weaknesses and strengths, so it is known to improving the ability of the school principal in conducting class supervision. The critical analysis of the school principal's ability to supervise the classes is done in accordance with predetermined indicators. The comparative technique referred to this study is to combine the results of the first and second cycle research, cycle II and third cycle. The result of the comparison is to know the indicator of success and the weaknesses in each cycle. Indicators that have not been achieved will be improved in the next cycle so that deficiencies that have been improved in the next cycle can improve the ability of the school principal in conducting class supervision.

\section{RESULTS}

This chapter presents the results of research in accordance with the formulation of the issues raised. Furthermore, there is a discussion of the research results.

\section{Description of initial condition about the Early ability of school principal of SMP Negeri 4 Sampang, SMP Negeri Atap 1 Torjun, SMP Sabilillah Sampang in conducting class supervision at their school.}

In this study, the data collected to compile the report was obtained from interviews, observation, grade compilation of supervision result, and questionnaire. The interview was conducted with the school principal of SMP Negeri 4 Sampang, school principal of SMP Atap 1 Torjun, school principal of SMP Sabilillah Sampang that this research will be conducted for three cycles and takes one month, November 2015. The discussion between the researcher and informants resulted in the agreement and some information about supervision class. Questionnaire of class supervision implementation is given before and after research activities.

To find out how the school principal understands in conducting the class supervision, the researcher used a questionnaire consisting of 15 statements. The statement consists of 5 (five) options. The score that used is 1 to 5 , so the maximum score to be achieved is 75 and the minimum score is 15 .

Based on the results of interviews and examination of learning tools, the school principal did not attach follow-up supervision results, from the 3 of school principals, 1 principal has not understood about academic supervision. This is because the school principal does not know the benefits of academic supervision for teachers and many other factors.

From the results of the questionnaire and examination results of the class supervision of the school principal, it was found that the school principal delegated senior teacher in performing class supervision and without control the result so that teachers' learning needs improvement and coaching cannot run properly. So the results do not achieve based on the expectations.

\section{Research Implementation}

The study was conducted in three cycles in a month. The improvement of understanding and using media and the selecting learning models is done by the way of socialization, and assistance in the preparation of class supervision instruments. The school principal develop a classroom supervision instrument in accordance with the characteristics of the learning process and characteristic of learning evaluation.

\section{Cycle I}

\section{Planning Action}

Principals are directed to develop classroom supervision instruments by adjusting the applicable provisions. In conducting classroom supervision, the principal is fully responsible for the results that can be used as a reference for teachers to improve learning which is acceptable to learners properly and correctly. 
Basically, learning in the classroom can be applied to various approach, strategy, and media of learning. Classroom supervision is done by the school principal in the hope that teachers as educators can receive input well and provide satisfactory learning outcomes.

\section{Implementing Action}

Socialization upon supervision of the class was done classical by the researcher. The materials of the socialization include the definition of supervision, the benefits of supervision and how to implement class supervision. After the socialization activities are completed, the school principal develops a classroom supervision instrument based on the existing provisions. But in SMP Negeri Atap 1 Torjun Sampang still use the senior teacher to carry out the supervision of the class, so the motivation of the teacher is not enough.

\section{Cycle II}

\section{Planning Action}

Based on the findings in the first cycle, the researcher plan the activities for cycle II, to carry out the assistance and socialization of individual classroom supervision, while the day is adjusted with the day of supervision visit to the target schools that is Monday to SMP Negeri 4 Sampang, Wednesday to SMP Sabilillah Sampang, and Saturday to SMP Atap 1 Torjun Sampang. The researcher conducts training on the preparation of class supervision instruments and the implementation of class supervision in each school.

\section{Implementing Action}

Cycle II is implemented in the second week of November 2015. Before mentoring, the researchers ask the principal about what obstacles are experienced during the supervision of the classroom? From some answers submitted by the school principal, one of them difficult to determine time implementation of supervision in the class? Based on the problem, the researcher gives assistance and socialization about the election time of the class supervision which is suitable for the situation and condition of the teacher and the school environment. While the right time is in the second month until fourth in each semester.

\section{Cycle III}

Based on the observation in cycle II, the researcher can find several things, such as the school principal cannot carry out the class supervision class and only depends on the senior teacher, while for the determination of the policy direction on teacher supervision result has no reference on the forms of policy and the school principals do not try to find new alternatives for the teachers.

\section{Planning Action}

In this third cycle, the researcher carried out individual training and mentoring in the hope that the school principals feel easier to understand and can be directly applied in the implementation of class supervision, therefore the researcher also conducted supervision of class visits with them.

\section{Implementing Action}

The third cycle begins in the third week of November 2015. Like the first two cycles, in the third cycle, the researcher is carrying out clinical training about the preparation of class supervision instruments, especially about the techniques and methods, the researcher conducted visits of class supervision according to the schedule that the researcher agreed with the school principals and teachers.

Generally, the cycle I, II, III can be compared as follows. After conducting the training to the school principal to understand the class supervision, it can be seen that the most of school principals have written techniques and how to supervise the class that will be used, when the researcher accompanies the principal in preparing the classroom supervision instrument, but it was not suitable existing provisions. After conducting the training to some school principals to understand the class supervision well, when researcher carries out supervision in the implementation of class supervision, an average of $38.4 \%$ of the school principals have written techniques and how to supervise the class that will be used when the implementation of supervision.

From the result of observation/observation in cycle II, the researcher find some things, that is: (a) the school principals have difficulty in choosing technique and method that are appropriate for situation and condition of school environment (b) the school principals are less creative (c) the school principals do not have many references to class supervision (d) the school principal consider that the class supervision does not motivate the teacher. After doing the assistance and socialization through groups and individuals, there 
has been an increase in understanding and application of classroom supervision. The understanding of 3 school principals about classroom supervision increased, but the increase was not followed by the creativity of the school principals to develop a classroom supervision instrument independently. From the results of observations that the researcher do in cycle II, the school principals still do many obstacles to develop a classroom supervision instrument related to the situation and condition of school environment, because their motivation for reading is still low, besides that the reference book they have are very limited, some even do not have supervision guidelines.

As long as the researcher conducts supervision to observe the school principal in supervising the class, the school principals often delegate a senior teacher, the teacher is enthusiastic to be supervised by the principal. After completion (implementation of supervision), the researcher holds a meeting with them, and they give the following comments: (1) It is very useful because this activity makes us know the duty and responsibility as the school principal. (2) It turns out that many things we do not know, we know now, such as supervision techniques. Supervision does not need to be delegated if we can understand the situation and the condition of the school environment (3) The activity planning should be done and very useful for the implementation of activities.

Based on the result of the research, Cycle I shows that $81 \%$ of teachers understand class supervision but cannot implement it according to the characteristics. Cycle II shows that there is an increase in understanding from (cycle I) the average score of $29,90 \%$ to $45,47 \%$. Cycle III shows that there is an increase in supervision competence, from the average (cycle II) score of $45.47 \%$ to $50.42 \%$.

\section{DISCUSSION}

Based on the research results, from cycle I to cycle III, the researcher found some problems faced by the schools related to how the implementation of class supervision: (1) The school principals is lack of understanding upon class supervision (2) The school principals are less creative, (3) The school principals are aware of conducting classroom supervision (4) The school principal always rely on senior teachers in conducting class supervision. Some of the mentioned above have been challenging for the researcher to change the school principals' images of classroom supervision. The researcher begins to alert them about supervising the class that the expected outcome was a change in the behavior of teachers from not knowing anything to know something about the improvement of good learning.

From the research results shows that with classical socialization, socialization in groups, individual socialization and assistance either group or individual turns out the best result is socialization and individual assistance. This shows that the school principal of SMP Negeri Sampang is more receptive to individual training. From the data mentioned above, it can be seen that at the time, the training, the school principals do not fully understand about class supervision. After being guided by the action, there is an increase although not significant. This is caused by several factors, there are: (1) The school principals do not have the motivation to develop. (2) They have not mastered ICT so that they cannot access to references from the internet.

From the data mentioned above, it is clearly found that after the socialization and assistance, the best results is through socialization and individual training. This indicates that the school principal of SMPN Sampang can change the pattern of supervision by using various techniques and ways to adjust to the situation and conditions in his school environment.

\section{CONCLUSION}

From the result of School Action Research (PTS) conducted in SMP Negeri 4 Sampang, SMP Atap 1 Torjun, and SMP Sabilillah Sampang, the school principals' competence in preparing the instrument and conducting class supervision increase in the ability after socialization, supervision and supervision academic/supervision class visits, it obtained $81 \%$ in Cycle I that the teachers understand class supervision but cannot implement it based on existing characteristics. In Cycle II, there is an increase in understanding from (cycle I) $29,90 \%$ on average reaches score to $45,47 \%$. In Cycle III, there is an increase in supervision competence, from the average (cycle II) of $45.47 \%$ reaches score to $50.42 \%$.

\section{REFERENCES}

Ilyas, Y. (1999). Kinerja. Teori, Penilaian dan Penelitian, Jakarta: FKM UI. 
Kependidikan, D. T., JENDERAL, D., Kependidikan, P. M. P. D. T., \& NASIONAL, D. P. (2008). Penilaian kinerja guru. Jakarta: Departemen Pendidikan Nasional.

Moleong, L. J. (2003). Metodologi Penelitain Kualitatif, Bandung, Penerbit PT.

Sutopo, H. B. (2002). Metodologi penelitian kualitatif. 